\title{
A Novel Application of Ionic Liquid in Improvement of The Felting Resistance of Wool
}

\author{
A. Kantouch, E. M. Khalil", H. El-Sayed ${ }^{\#}$ and S. Mowafi \\ Textile Research Division, National Research Centre and \\ *Department of Chemistry, Faculty of Science, Helwan \\ University, Cairo, Egypt.
}

\begin{abstract}
7 HE EFFECT of treatment of wool using two different ionic liquids namely 1-ethyl -3-methyl imidazolium acetate (EMIA), and 1-butyl -3-methyl imidazolium chloride (BMIC), on the felting resistance of wool was studied. The effect of treatment temperature and treatment time on the yellowing index, tenacity, and elongation at break of the treated wool fibres, was examined. Elemental analysis elucidated a remarkable reduction in sulphur content of the treated wool, which is mainly present in the wool scales. Scanning electron microscopy confirmed partial removal of wool scales under the effect of ionic liquid.
\end{abstract}

Keywords: Wool fibre, Ionic liquid, Imidazolium salts and Anti-felting.

Felting of wool is due to its scaly surface that point away from the fibre root and overlap like tiles on a roof. The protruding scale edges result in differential friction between the with-scale and against-scale direction, which under some conditions results in irreversible migration of individual fibres toward their rootends ${ }^{(1)}$. The most common shrink-proofing treatment (chlorine-Hercosett) still uses chlorine, which pollutes effluents with adsorbable organo halogens (AOX) by-products ${ }^{(2)}$.

Recent research has been directed toward environmental aspects of the shrink-resist treatment of wool, particularly the reduction or elimination of organochlorine compounds in effluents. Modifications of wool surface morphology were conducted either by chemical degradation of the wool scales or by deposition of polymer on the scales ${ }^{(3-5)}$. A wide range of enzymatic treatments are being studied as an ecological and economical way ${ }^{(6-14)}$. Moreover, low temperature plasma was regarded as an environmentally friendly process to achieve the effect of an anti-felt finishing in wool ${ }^{(14-18)}$.

The ionic liquid (IL) refers to organic or inorganic ionic salts whose melting points are relatively low, have non-measureable vapour pressure, limited flammability, and high thermal stability ${ }^{(19)}$. The ionic liquid consists mainly of an organic cation, such as 1-alkyl-3-methylimidazolium, 1-alkyl pyridinium, or 1-methyl-1-alkyl pyrrolidinium and counter-ions such as halides, acetate, ethyl sulphate, tetraflouro borate, and hexaflouro phosphate..., etc.

\# E-mail: hosam@trdegypt.org 
Recent publication has shown the possibility of dissolution different materials in ionic liquids including cellulose and wool, for different industrial purposes $^{(21,22)}$. Moreover, ionic liquids which have good solubility for wool keratin were employed to treat the wool fiber for improving its dyeability ${ }^{(21-23)}$.

Previous work in our labs showed that, improvement on the dyeability of wool fiber treated by ionic liquid is due to partial descaling of wool ${ }^{(24)}$. In this study, the effect of treatment of wool fiber using two different ionic liquids on improving its antifelting properties was assessed.

\section{Experimental}

Materials

Scoured Australian merino wool tops were supplied from Misr Company for Spinning and Weaving, El-Mehalla El-Kobra, Egypt. The properties of these wool tops are summarized in Table 1.

TABLE 1. Properties of the used wool fibers.

\begin{tabular}{|l|c|}
\hline Property & Value \\
\hline Mean fibre diameter & 19.6 micron \\
\hline Fibre strength & $11.5 \mathrm{cN} /$ tex \\
\hline Alkali solubility & $15.2 \%$ \\
\hline Urea-bisulphite solubility $(\%)$ & $46.5 \%$ \\
\hline Yellowing index & 33.41 \\
\hline
\end{tabular}

\section{Chemicals}

1-Butyl-3-methyl imidazolium chloride (BMIC) was purchased from Merck, Steinheim, Germany and 1- Ethyl-3-methyl imidazolium acetate (EMIA) was purchased from Io-li-tec, Denzlingen, Germany. Egyptol PLM nonionic detergent based on nonyl phenol ethoxylate was supplied from Starch and Brewer's Company, Alexandria, Egypt. All other chemicals are of laboratory grade chemicals.

\section{Methods}

Scouring

Wool tops were scoured in a bath containing $1 \mathrm{~g} / \mathrm{l}$ Egyptol PLM for $30 \mathrm{~min}$ at $60{ }^{\circ} \mathrm{C}$. The fibre was then rinsed thoroughly with running water, squeezed, and finally air-dried at ambient temperature.

Treatment with ionic liquid

The scoured wool fibre was immersed for two minutes in aqueous or nonaqueous solution containing $5 \% \mathrm{w} / \mathrm{w}$ of BMIC or EMIA in water or in 1propanol. The samples were mangle-squeezed to a pick up of $80 \%$ and so the ionic liquid content is $4 \%$ on the weight of the fibre (owf).

Egypt. J. Chem. 54, No. 4 (2011) 
Drying

The treated wool samples were dried and left for different periods (10-60 min) at various temperatures; (100-120) ${ }^{\circ} \mathrm{C}$ in case of EIMA, and $120^{\circ} \mathrm{C} \&$ $130^{\circ} \mathrm{C}$ in case of BMIC to remove residual water or organic solvent. After drying and heating, the samples were washed with water for several times and air-dried before being subjected to the felting test. The washing water containing ionic liquids was filtered to remove any residual fibers, and the residual ionic liquid was recovered by distillation under vacuum.

Analyses

Felting test

The Aachener three-dimensional shaking machine was used to produce felt balls according to IWTO 20-69 test method $^{(25)}$.

Yellowness index

The yellowness index of wool fibre was measured using Ultra Scan PRO, Standards Box, S/n: USP 1229, Hunter Lab. Yellowness index (YI) was determined using ASTM method (E 313) according to the following equation:

$$
\mathrm{YI}_{(\mathrm{E} 313)}=100[1-(0.847 \mathrm{Z} / \mathrm{Y})]
$$

where $\mathrm{Y}$ and $\mathrm{Z}$ are the first numerical scale offered to quantify colour.

Elemental analysis

The amount of carbon, nitrogen, hydrogen, and sulphur, in the untreated and selected treated wool fibers were assessed using Elementary CHNS Analyser, Model Vario EL III, Germany.

\section{Mechanical properties}

The mechanical properties of the bundle untreated and the ionic liquid treated wool fibers were measured using INSTRON- assembled in USA, Load cell $100 \mathrm{~N}$.

Scanning Electron Microscopy

The untreated as well as the treated wool fabrics were mounted on aluminium stubs sputter coated with gold in an S150A sputter (Edward, UK), and examined by JEOL (JXA-840A) Electron Probe Microanalyzer (Japan).

\section{Results and Discussion}

The effect of treatment of wool fibres using ionic liquids (ILs); namely 1ethyl-3-methyl imidazolium acetate (EMIA) and 1-butyl-3-methyl imidazolium chloride (BMIC) on their felting resistance was monitored. Water or 1-propanol was used as a diluent for the used ILs to decrease the consumption of the used ILs and to minimize any deterioration that might take place to the substrate under the influence of the pure ionic liquid. 
The Aachener three-dimensional shaking machine was used to produce felt balls according to IWTO 20-69 test method. The diameter of the formed felt balls was taken as a measure of the degree of felting; as the felting resistance increases the diameter of the felt ball increases.

Treatment with 1-ethyl-3-methyl imidazolium acetate (EMIA)

Effect of diluents

The effect of treatment of wool fiber with $5 \%$ (w/w) EMIA/propanol or EMIA/water and drying at $120{ }^{\circ} \mathrm{C}$ for different intervals on the felting resistance was studied and tabulated in Table 2.

TABLE 2. Effect of treatment of wool fibre with $5 \%$ (w/w) EMIA in propanol or water at $120{ }^{\circ} \mathrm{C}$ for different times on its felting resistance.

\begin{tabular}{|c|c|c|}
\hline Diluting agent & Treatment Time (min) & $\begin{array}{c}\text { Felt ball diameter } \\
(\mathbf{c m})\end{array}$ \\
\hline \multirow{4}{*}{ Water } & 10 & 2.95 \\
\cline { 2 - 3 } & 20 & 2.88 \\
\cline { 2 - 3 } & 30 & 2.79 \\
\cline { 2 - 3 } & 40 & 2.81 \\
\cline { 2 - 3 } & 50 & 3.07 \\
\hline \multirow{4}{*}{ Propanol } & 60 & 3 \\
\cline { 2 - 3 } & 10 & 3.73 \\
\cline { 2 - 3 } & 20 & 3.8 \\
\cline { 2 - 3 } & 30 & 3.71 \\
\cline { 2 - 3 } & 40 & 3.8 \\
\cline { 2 - 3 } & 50 & 3.8 \\
\hline
\end{tabular}

Results in Table 2 showed that, at the same drying time and temperature the diameter of the felting balls of the wool fibers treated with EMIA/propanol are greater than those of the fibers treated with EMIA/water. This may be due to the rapid evaporation of propanol, characterized by lower boiling point than water, leading to early starting the action of ionic liquid and early etching of wool scales.

\section{Effect of treatment conditions}

The effect of treatment of wool with EMIA at different conditions, i.e. temperature and time were studied.

Results of this investigation, given in Table 3, show that the diameter of the felting balls of the treated fibers is greater than that of the untreated ones. This can be attributed to partial removal of wool scale under the action of the used ionic liquid resulting in a smooth fibre surface and an enhancement of the antifelting property of wool. Kantouch et al. have studied the morphological structure of wool fibres treated with EMIA by scanning electron microscopy and confirmed partial de-scaling of the treated fibres ${ }^{(24)}$.

Egypt. J. Chem. 54, No. 4 (2011) 
Table 3 clarifies also that at the same drying temperature of the treatment, the felting resistance of the treated wool was improved by increasing the drying time. As the drying temperature increased the felting resistance increased. At $120^{\circ} \mathrm{C}$, the felt balls have a relatively deformed ball indicating higher felting resistance of wool.

TABLE 3. Effect of treatment of wool fibre with $5 \%$ (w/w) EMIA in propanol at different temperatures for different times on its felting resistance.

\begin{tabular}{|c|c|c|}
\hline $\begin{array}{c}\text { Treatment temperature } \\
\left({ }^{\circ} \mathbf{C}\right)\end{array}$ & Treatment time (min) & $\begin{array}{c}\text { Felt ball diameter } \\
(\mathbf{c m})\end{array}$ \\
\hline Untreated & - & 2.57 \\
\hline \multirow{4}{*}{100} & 10 & 2.61 \\
\cline { 2 - 3 } & 20 & 3.06 \\
\cline { 2 - 3 } & 30 & 3.32 \\
\cline { 2 - 3 } & 40 & 3.31 \\
\cline { 2 - 3 } & 50 & 3.57 \\
\hline \multirow{4}{*}{110} & 60 & 3.57 \\
\cline { 2 - 3 } & 10 & 2.96 \\
\cline { 2 - 3 } & 20 & 3.35 \\
\cline { 2 - 3 } & 30 & 3.46 \\
\cline { 2 - 3 } & 40 & 3.75 \\
\cline { 2 - 3 } & 50 & 3.51 \\
\hline \multirow{4}{*}{120} & 60 & 3.78 \\
\cline { 2 - 3 } & 10 & 3.73 \\
\cline { 2 - 3 } & 20 & 3.8 \\
\cline { 2 - 3 } & 30 & 3.71 \\
\cline { 2 - 3 } & 40 & 3.8 \\
\cline { 2 - 3 } & 50 & 3.8 \\
\hline \multirow{4}{*}{} & 60 & 3.81 \\
\hline
\end{tabular}

The effect of treatment with 1-butyl-3-methyl imidazolium chloride (BIMIC)

The effect of treatment of wool with BIMIC at different temperature (120 $130{ }^{\circ} \mathrm{C}$ ) for various periods $(10-60 \mathrm{~min})$ on the antifelting behavior is shown in Table 4.

Table 4 shows that, there is a slight increase in the diameter of the felting balls of the BIMIC treated wool fiber as compared with the untreated ones. A maximum of felt ball diameter of $2.9 \mathrm{~cm}$ was obtained by treatment with this reagent at $130{ }^{\circ} \mathrm{C}$ for $60 \mathrm{~min}$.

The relatively higher effect of 1- Ethyl-3-methyl imidazolium acetate (EMIA) as compared with 1-butyl-3-methyl imidazolium chloride (BMIC) may be due to the relatively small molecular volume of the EMIA compared to the BMIC which results in fast and easy penetration of the EMIA in the voids of wool fiber. 
TABLE 4. Effect of treatment of wool fibre with $5 \%$ (w/w) BIMIC in propanol at different temperatures for different periods on its felting resistance.

\begin{tabular}{|c|c|c|}
\hline $\begin{array}{c}\text { Treatment Temperature } \\
\left({ }^{\circ} \mathbf{C}\right)\end{array}$ & Treatment Time (min) & $\begin{array}{c}\text { Felt Ball Diameter } \\
(\mathbf{c m})\end{array}$ \\
\hline Untreated & - & 2.57 \\
\hline \multirow{4}{*}{120} & 10 & 2.57 \\
\cline { 2 - 3 } & 20 & 2.58 \\
\cline { 2 - 3 } & 30 & 2.59 \\
\cline { 2 - 3 } & 40 & 2.62 \\
\cline { 2 - 3 } & 50 & 2.62 \\
\cline { 2 - 3 } & 60 & 2.64 \\
\hline \multirow{5}{*}{130} & 10 & 2.57 \\
\cline { 2 - 3 } & 20 & 2.58 \\
\cline { 2 - 3 } & 30 & 2.66 \\
\cline { 2 - 3 } & 40 & 2.69 \\
\cline { 2 - 3 } & 50 & 2.83 \\
\cline { 2 - 3 } & 60 & 2.9 \\
\hline
\end{tabular}

Elemental analysis

Nitrogen, carbon, sulphur, and hydrogen contents of selected treated wool with EMIA or with BIMIC as well as the untreated wool were determined .

Results of this analysis, tabulated in Table 5, show that there is a slight decrease in sulphur content of the BIMIC treated fibers, (3\%), as compared with sulphur content of the untreated fiber. On the other hand, the sulphur content of the EMIA treated wool decreased by about $10 \%$ as compared to the untreated wool. This decrease in sulphur content can be explained in terms of the partial removal of wool scales, rich in sulphur, under the effect of the ionic liquid EMIA. On the other hand, there is no remarkable change in nitrogen, carbon or hydrogen contents which may indicate that, this treatment has a physical effect and not a chemical one.

TABLE 5. C, H, S, and N contents of wool fiber treated with 5\% EMIA \& BIMIC.

\begin{tabular}{|l|c|c|c|c|}
\hline Sample & $\mathbf{N \%}$ & $\mathbf{C \%}$ & $\mathbf{S \%}$ & $\mathbf{H \%}$ \\
\hline Blank & 14.9 & 44.9 & 3.0 & 10.2 \\
\hline BIMIC at $120^{\circ} \mathrm{C}$ for $60 \mathrm{~min}$ & 15.1 & 44.8 & 3.0 & 10.2 \\
\hline BIMIC at $140^{\circ} \mathrm{C}$ for $60 \mathrm{~min}$ & 14.9 & 44.4 & 2.9 & 11.4 \\
\hline BIMIC at $150^{\circ} \mathrm{C}$ for $50 \mathrm{~min}$ & 15.0 & 45.1 & 2.9 & 10.4 \\
\hline EMIA at $100^{\circ} \mathrm{C}$ for $60 \mathrm{~min}$ & 15.0 & 44.7 & 2.9 & 11.2 \\
\hline EMIA at $110^{\circ} \mathrm{C}$ for $60 \mathrm{~min}$ & 15.0 & 44.9 & 2.7 & 10.2 \\
\hline EMIA at $120^{\circ} \mathrm{C}$ for $20 \mathrm{~min}$ & 15.1 & 45.1 & 2.7 & 11.0 \\
\hline
\end{tabular}

Yellowning index

The effect of treatment of wool fibers with the two ionic liquids EMIA and BIMIC at different temperatures for several intervals on the yellowness of the fiber was studied and the results are tabulated in Tables 6 and 7. 
TABLE 6. The effect of treatment of wool fiber with $5 \%$ EMIA in propanol on the yellowness of the fiber

\begin{tabular}{|c|c|c|}
\hline $\begin{array}{c}\text { Treatment Temperature } \\
\left({ }^{\circ} \mathbf{C}\right)\end{array}$ & Treatment Time (min) & Yellowness \\
\hline Untreated & - & 33.94 \\
\hline \multirow{5}{*}{100} & 10 & 33.5 \\
\cline { 2 - 3 } & 20 & 35.16 \\
\cline { 2 - 3 } & 30 & 35.3 \\
\cline { 2 - 3 } & 40 & 35.52 \\
\cline { 2 - 3 } & 50 & 36.43 \\
\hline \multirow{5}{*}{110} & 60 & 37.46 \\
\cline { 2 - 3 } & 10 & 30.57 \\
\cline { 2 - 3 } & 20 & 33.68 \\
\cline { 2 - 3 } & 30 & 36.82 \\
\cline { 2 - 3 } & 40 & 37.1 \\
\cline { 2 - 3 } & 50 & 35.62 \\
\cline { 2 - 3 } & 60 & 34.86 \\
\cline { 2 - 3 } & 10 & 27.43 \\
\cline { 2 - 3 } & 20 & 36.33 \\
\cline { 2 - 3 } & 30 & 36.55 \\
\cline { 2 - 3 } & 40 & 37.79 \\
\cline { 2 - 3 } & 50 & 38.09 \\
\hline \multirow{5}{*}{120} & 60 & 38.03 \\
\hline
\end{tabular}

TABLE 7. The effect of treatment of wool fiber with $5 \%$ BIMIC in propanol on the yellowness of the fiber

\begin{tabular}{|c|c|c|}
\hline $\begin{array}{c}\text { Treatment Temperature } \\
\left({ }^{\circ} \mathbf{C}\right)\end{array}$ & Treatment Time (min) & Yellowness \\
\hline Untreated & - & 33.94 \\
\hline \multirow{4}{*}{120} & 10 & 34.81 \\
\cline { 2 - 3 } & 20 & 35.31 \\
\cline { 2 - 3 } & 30 & 36.43 \\
\cline { 2 - 3 } & 40 & 37.09 \\
\cline { 2 - 3 } & 50 & 37.65 \\
\hline \multirow{5}{*}{130} & 60 & 40.25 \\
\cline { 2 - 3 } & 10 & 37.72 \\
\cline { 2 - 3 } & 20 & 38.98 \\
\cline { 2 - 3 } & 30 & 39.62 \\
\cline { 2 - 3 } & 40 & 41.84 \\
\cline { 2 - 3 } & 50 & 42.50 \\
\cline { 2 - 3 } & 60 & 43.87 \\
\hline
\end{tabular}

Egypt. J. Chem. 54, No. 4 (2011) 
Table 6 clarifies that the treatment of wool fiber with the ionic liquid 1-ethyl3-methyl imidazolium acetate (EMIA) has a very slight effect on the yellowness of the treated fiber as compared to the untreated wool.

On the other hand, data of Table 7 show that, the treatment of wool fiber with the ionic liquid 1-butyl -3-methyl imidazolium chloride (BMIC) results in remarkable yellowing of wool that increases on increasing the treatment temperatures.

\section{Mechanical properties}

The mechanical properties of the ILs-treated as well as the untreated wool fibres were examind, and the data are tabulated in Tables 8 and 9.

TABLE 8. Tensile strength and strain at break of the treated wool fiber with $5 \%$ EMIA in propanol at different temperatures for various intervals.

\begin{tabular}{|c|c|c|c|}
\hline \multicolumn{2}{|c|}{ Treatment } & \multirow{2}{*}{$\begin{array}{c}\text { Tensile strength } \\
\text { (g/den) }\end{array}$} & \multirow[b]{2}{*}{ Strain at break $(\%)$} \\
\hline Temperature $\left({ }^{\circ} \mathbf{C}\right)$ & Time (min) & & \\
\hline Untreated & -- & 0.024 & 42.53 \\
\hline \multirow{6}{*}{100} & 10 & 0.020 & 41.11 \\
\hline & 20 & 0.0161 & 38.29 \\
\hline & 30 & 0.0149 & 35.82 \\
\hline & 40 & 0.0135 & 32.61 \\
\hline & 50 & 0.0134 & 29.00 \\
\hline & 60 & 0.013 & 26.11 \\
\hline \multirow{6}{*}{110} & 10 & 0.0185 & 48.00 \\
\hline & 20 & 0.0132 & 32.22 \\
\hline & 30 & 0.0122 & 31.67 \\
\hline & 40 & 0.0111 & 27.23 \\
\hline & 50 & 0.0092 & 22.22 \\
\hline & 60 & 0.0086 & 19.44 \\
\hline \multirow{6}{*}{120} & 10 & 0.0165 & 30.05 \\
\hline & 20 & 0.0093 & 22.78 \\
\hline & 30 & 0.0092 & 20.26 \\
\hline & 40 & 0.0089 & 18.53 \\
\hline & 50 & 0.0078 & 17.22 \\
\hline & 60 & 0.0069 & 17.01 \\
\hline
\end{tabular}

Data of the table clarify that, the tenacity of the trerated fibres decreases as a function of the treatment time and temperature. An acceptable felting resistance was imparted to wool fibres upon treatment with EMIA at $100{ }^{\circ} \mathrm{C}$ for $20 \mathrm{~min}$ at which the less in tensile strength was $20 \%$. Further study would be carried out to decrease the loss of tensile properties of the treatd fibre to a minimum value.

On the other hand, limited loss in tensile strength of the treated fibres was encountred upon treatment with BMIC; a result which is in harmony with the felting resistance data in Table 4.

Egypt. J. Chem. 54, No. 4 (2011) 
Similar results have been recorded for the loss of elongation at break of the treated wool fibres.

TABLE 9. Tensile strength and strain at break of the treated wool fiber with $5 \%$ BIMIC in propanol at different temperatures for various intervals.

\begin{tabular}{|c|c|c|c|}
\hline & & & \\
\hline \multicolumn{2}{|c|}{ Treatment } & \multirow{2}{*}{$\begin{array}{c}\text { Tensile strength } \\
\text { (g/den) }\end{array}$} & \multirow[b]{2}{*}{ Strain at break $(\%)$} \\
\hline Temperature $\left({ }^{\circ} \mathbf{C}\right)$ & Time (min) & & \\
\hline \multicolumn{2}{|c|}{ Untreated } & 0.024 & 42.53 \\
\hline \multirow{6}{*}{120} & 10 & 0.026 & 41.23 \\
\hline & 20 & 0.025 & 40.03 \\
\hline & 30 & 0.024 & 40 \\
\hline & 40 & 0.0239 & 38.8 \\
\hline & 50 & 0.0226 & 38.09 \\
\hline & 60 & 0.0195 & 37.78 \\
\hline \multirow{6}{*}{130} & 10 & 0.0258 & 41.92 \\
\hline & 20 & 0.0239 & 40.0 \\
\hline & 30 & 0.0232 & 39.91 \\
\hline & 40 & 0.0197 & 37.88 \\
\hline & 50 & 0.0183 & 37.00 \\
\hline & 60 & 0.0180 & 35.96 \\
\hline
\end{tabular}

Scanning Electron Microscopy

The scanning electron micrographs of untreated as well as wool fiber treated with either EMIA or BMIC are shown in Fig. 1-3.

These Figures show that the morphological structure of wool has been significantly modified as a result of pre-treatment with the said ionic liquids.

Whereas Fig. 1 shows the normal scaly structure of wool fibres, Fig. 3 reveals that there is removal and deterioration in the scales on the fibre surface; under the effect of EMIA, resulting in an improvement of the anti-felting propeties of wool fiber. Figure 2 shows only slight deterioration in wool scales after treated with BMIC 


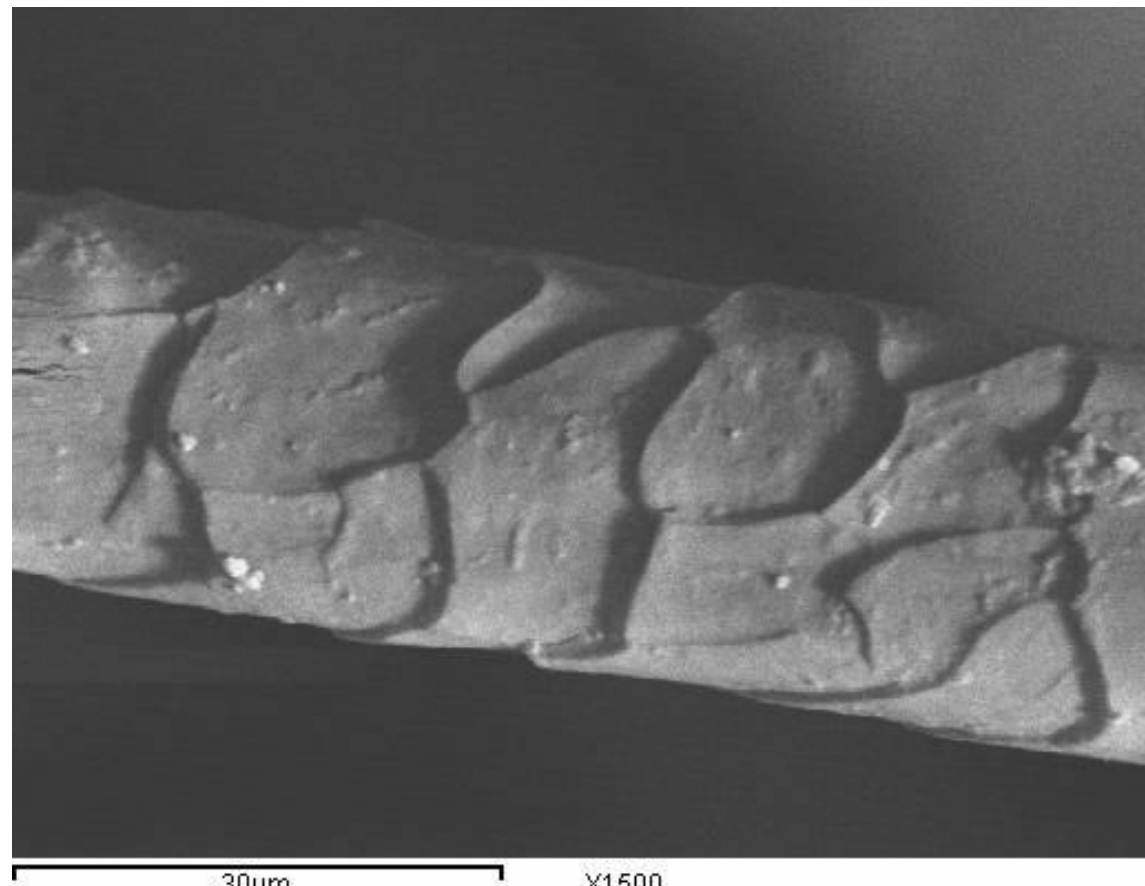

$30 \mu \mathrm{m}$

Fig. 1. SEM of untreated wool fibers

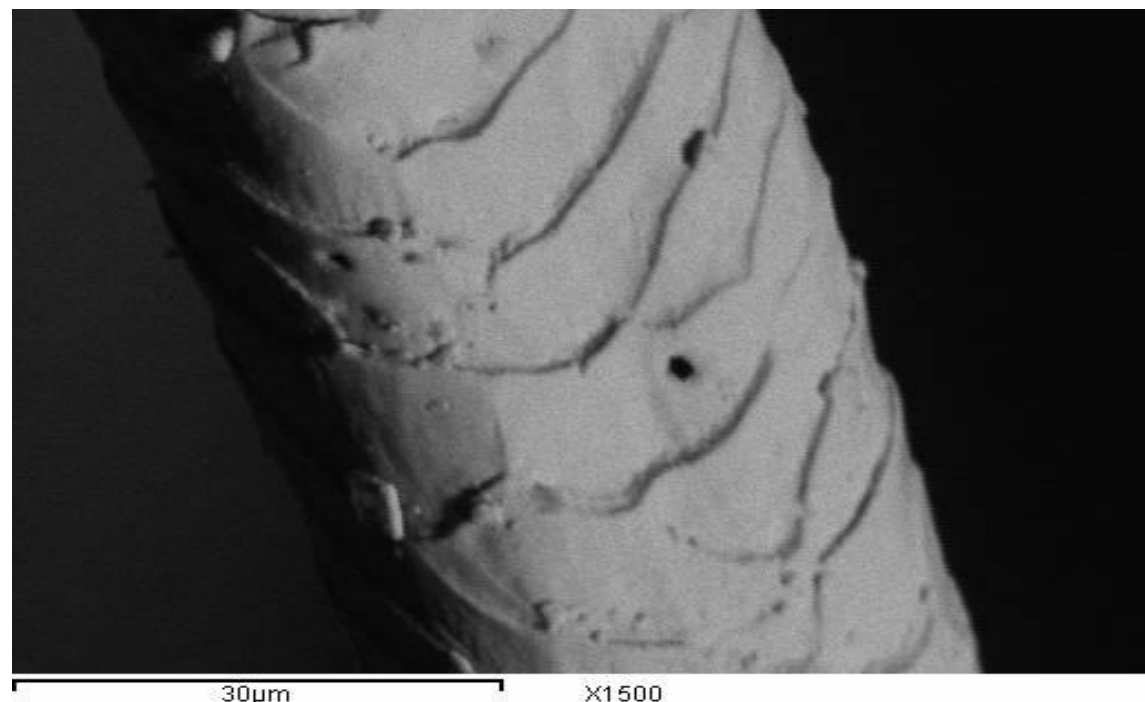

Fig. 2. SEM of wool fibre treated with $5 \%$ BIMIC and dried at $130^{\circ} \mathrm{C}$ for $50 \mathrm{~min}$. 


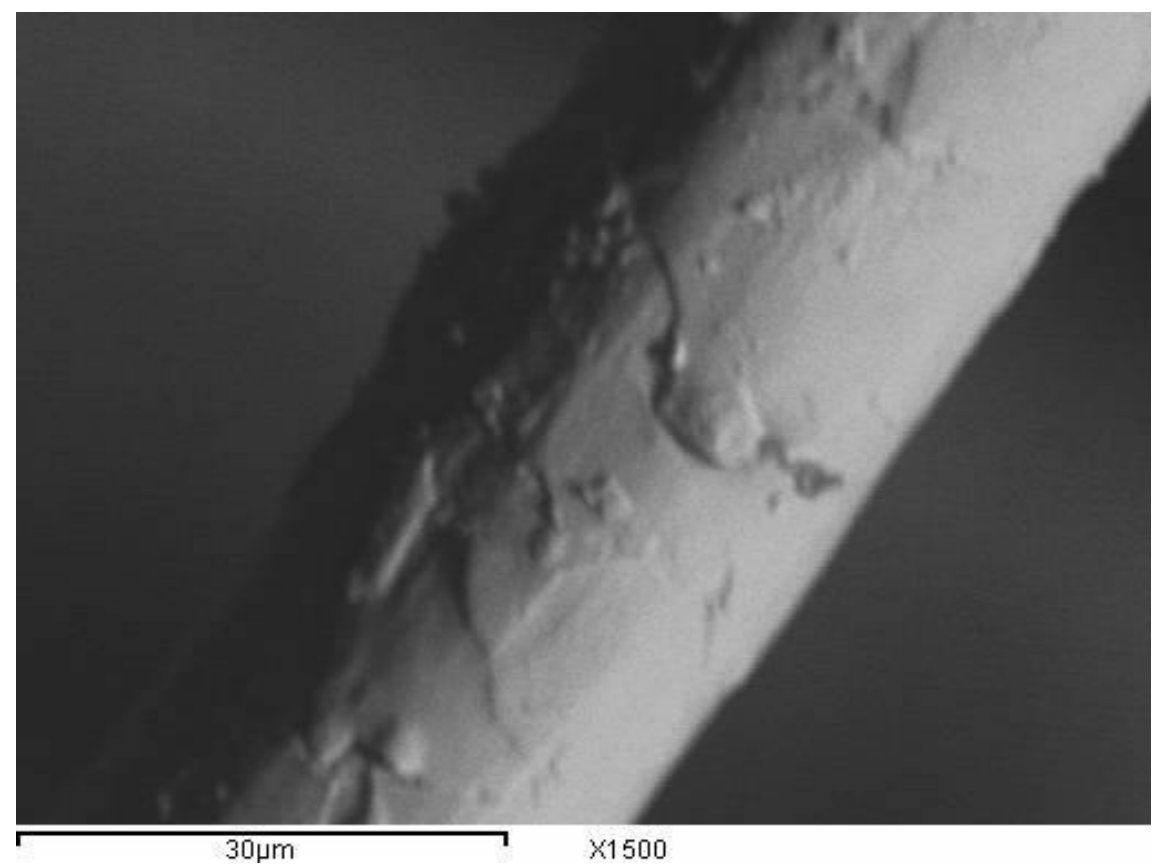

Fig. 3. SEM of wool fibre treated with $5 \%$ EMIA and dried at $120^{\circ} \mathrm{C}$ for $20 \mathrm{~min}$.

\section{Conclusion}

The treatment of wool fiber using 1-ethyl -3-methyl imidazolium acetate (EMIA) has relatively high improvement in the antifelting properties. Elemental analysis shows that this treatment reduces the sulphur content of the treated fibers due to removal of wool scales, rich in sulphur, under the action of the ionic liquid EMIA. Yellwoness of the EMIA treated wool fiber is slightly increased by this treatment. Scanning electron micrographs reveals that there is removal and deterioration in the scales on the wool fibre surface; under the action of EMIA, that resulted in improvement of its anti-felting properties.

\section{References}

1. Makinson, K. R., Shrinkproofing of Wool ; New York Marceldekker (1979)

2. Haefely, H. R., Enzymatische behandlung von Wolle. Textilveredlung, 24, 271-276 (1989)

3. Kantouch, A., El-Sayed. H., and El-Sayed. A., Improvement of the felting and shrinking resistance of wool using environmentally acceptable treatments. J. Text. Inst. 98, 65 (2007)

4. El-Sayed, H. and El-Khatib, E., Modification of wool fabric using ecologically acceptable UV-assisted treatments. J. Chem. Technol. Biotechnol. 80, 1111 (2005) . 
5. Roberts, G. and Wood, F., A Study of the influence of structure on the effectiveness of chitosan as an antifelting treatment for wool. Journal of Biotechnology, 89, 297 (2001).

6. Shen, J., Rushforth, M., Cavaco-Paulo, A., Guebitz, G. and Lenting, H., Development and industrialisation of enzymatic shrink-resist process based on modified proteases for wool machine washability. Enzyme and Microbial Technology, 37 (2006)

7. Silva, C. J. S. M., Prabaharan, M., Gübitz, G. and Cavaco-Paulo, A., Treatment of wool fibres with subtilisin and subtilisin-PEG. Enzyme and Microbial Technology, 36, 917-922 (2005).

8. Rao, M. B., Tanksale, A. M., Ghatge, M. S. and Deshpande, V. V., Molecular and biotechnological aspects of microbial proteases. Microbiology and Molecular Biology Reviews, 6, 597-635 (1998).

9. Heine, E., Hollefelder, B., Lorenz, W., Thomas, H., Wortmann, G. and Höcker, H., Enzymes for Wool Fiber Modification, 279 - 293 American Chemical Society (1998).

10. El-Sayed, H., Kantouch, A., Heine, E. and Höcker, H., Developing a zero-AOX shrink-resist process for wool. Part 1: Preliminary results. Coloration Technology, 117, $234-238$ (2001).

11. El - Sayed, H., Hamed, R. R., Kantouch, A., Heine, E. and Höcker, H., Enzyme based feltproofing of wool. AATCC Review, 25 - 28 (2002).

12. Dong, L. and XU, L., Enzymatic process for the wool fabric antifelting finishing. Modern Applied Science, 2, 91-93 (2008).

13. Cui, S. and Zhang, X., Application of proteinase as a modifying agent for wool fiber. Wool Textile Journal, 35, 17-19 (2006).

14. Bureau, E.I., "IPPC Reference Document on Best Available Techniques for the Textile Industry", (European Comission, Directorate General JRC, Seville (2003).

16. Tomasino, G. and Cuomo, J., Annual Report. National Textile Center, North Carolina State (1994).

17. Rybkin, V. V., Maximov, A.L., Gorberg, B.L. and Titov, V.A., Asian Text. J. 6, 30 (1997).

18. Subbulakshmi, M. S. and Hansraj, K.N., Indian J. Text. 109, 12 (1998) .

19. Molina, R., Canal, C., Bertrán, E., Tascón, J. M. D. and Erra, P., Low temperature plasma modified wool fabrics: surface study by SEM. Multidisciplinary Microscopy Research and Education, 242-249 (2004).

20. Laus, G., Bentivoglio, G., Schotterberger, H., Kahlenber, V., Kopacka, H., Thomas Roeder and Sixta. H., Ionic liquids: Current developments, potential and drawbacks for industrial applications, Lenzinger Berichter, 84, 71 - 85 (2005).

Egypt. J. Chem. 54, No. 4 (2011) 
21. Swatloski, R.P., Spear, S.K., John, D., Holbrey, J.D. and Rogres, R.D. Dissolution of cellulose in ionic liquids. J. Am. Chem. Soc. 124, 4974 (2002).

22. Xie, H., Li, S. and Zhang, S., ionic liquids as novel solvents for the dissolution of wool keratin fibers. Green. Chem. 7, 606 (2005).

23. Jiugang, Y., Qiang, W., Xuerong, F. and Ping, W., Enhancing dye adsorption of wool fibers with 1-butyl-3-methylimidazolium chloride ionic liquid processing. Textile Research Journal, 80, 1898 (2010).

24. Jiugang, Y., Qiang, W. and Xuerong. F., Dyeing behaviors of ionic liquid treated wool. Journal of Applied Polymer Science; 117, 2278 (2010)

25. Kantouch, A., Khalil, E.M., Mowafi, S., Allam, G.O. and El-Sayed, H., Utilization of ionic liquids for low temperature dyeing of proteinic fabrics. accepted for publication in Egypt. J. Chem (2011).

26. IWTO Test Method, 20-69

( Received 14/11/2011;

accepted 4/12/2011)

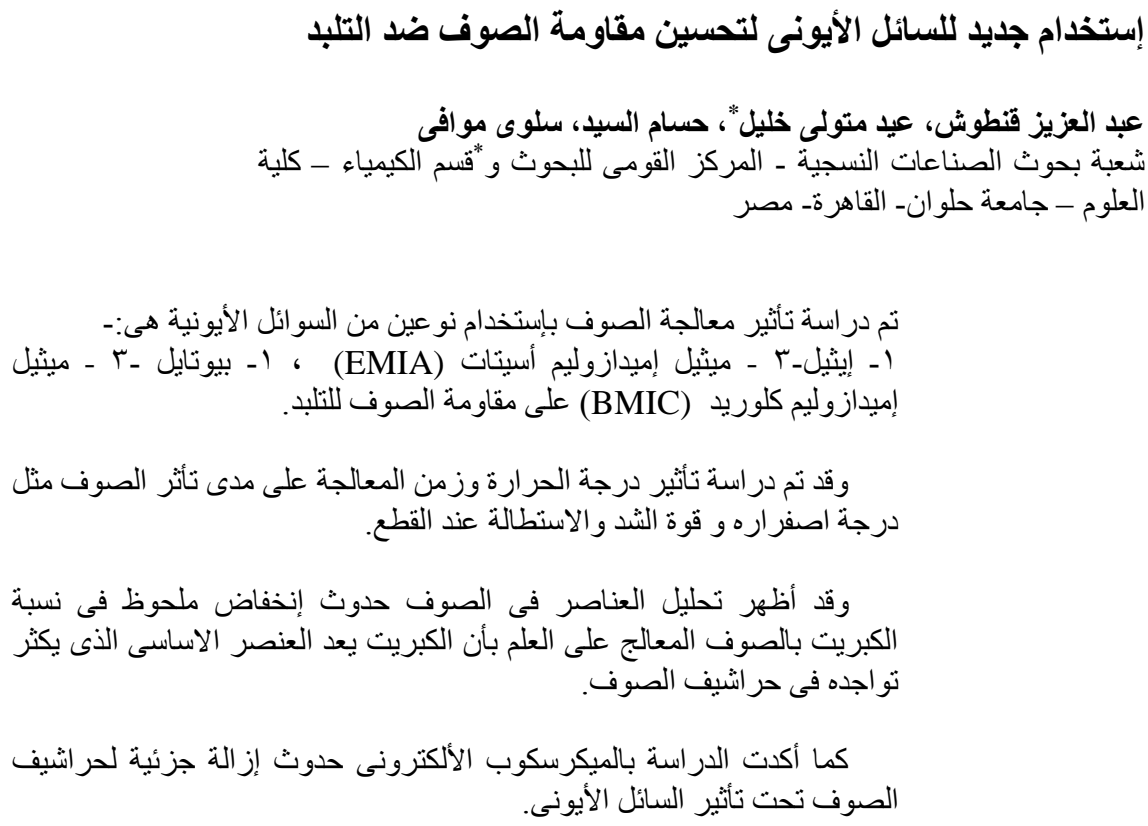

